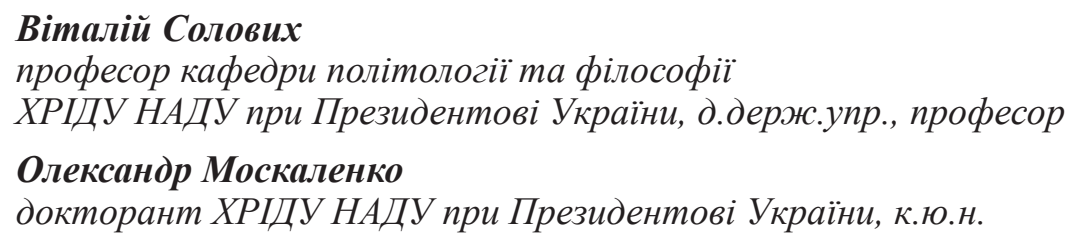

\title{
СПІЛЬНА ЗОВНІШНЯ ПОЛІТИКА ТА ПОЛІТИКА БЕЗПЕКИ НА СУЧАСНОМУ ЕТАПІ РОЗВИТКУ СВРОПЕЙСЬКОГО СОЮЗУ
}

\begin{abstract}
Стаття присвячена вивченню спільної зовнішньої політики та політики безпеки на сучасному етапі розвитку Європейського Союзу. У статті проаналізовано ініціативи, направлені на посилення цієї політики останніми роками, а також основні напрямки розвитку иієі політики з точки зору необхідності для СС реагувати на сучасні безпекові виклики як глобального, так і регіонального характеру. Основним висновком аналізу є твердження про необхідність трансформації СЗППБ, що включає в себе формування синергії з іншими політиками в рамках спільної зовнішньої політики СС та поширення на СЗППБ загальних принципів та підходів, що існують у конституційному порядку $С С$. Зазначений процес розпочався, незважаючи на існуючі обмеження, встановлені правилами Лісабонського договору. Ключові слова: СЗППБ; СС; міжнародна безпека; безпекові виклики; збройний конфлікт; Політика Сусідства.
\end{abstract}

Vitaly Solovykh

professor of the Department of Political Sciences and Philosophy, KhRIPA NAPA under the President of Ukraine, Doctor of Sciences in Public Administration, Professor

Oleksandr Moskalenko

Researcher for the degree of Habilitated Doctor, Department of Political Sciences and Philosophy, KhRIPA NAPA under the President of Ukraine, PhD in Legal Sciences

\section{THE COMMON FOREIGN AND SECURITY POLICY AT THE CONTEMPORARY STAGE OF THE EVOLUTION OF THE EUROPEAN UNION}

The article is dedicated to the study of Common Foreign and Security Policy at the contemporary stage of the EU evolution. The article provides the analysis of both initiatives aimed at enhancing this policy, which have already been initiated in recent years and the major directions of the transformation of this policy from the perspective of the necessity for the EU to face the contemporary security challenges at the global and regional level. The article refers to the fact that the European integration process has always had the security dimension as the entire project was started to prevent another war between France and Germany, which had previously been the major reason for two world wars. The EU's enlargement after the end of the Cold war also had the security dimension as this process reconnected the European continent previously divided by the «iron curtain». The fact that the new EU members from the Central and Eastern Europe simultaneously became members of NATO only stresses this approach. Thus, security has been among the major issue in the EU relations with its neighbouring countries and primarily within the framework of the EU's Neighbourhood Policy and Eastern Partnership.

However, new security challenges for the EU which appeared in the connection with its attempts to enhance its relations with the neighbouring countries emphasized the need to modernize its common and security policy (CFSP), which remains a separate policy area with its special rules and procedures as provided for by the Lisbon Treaty.

The aim of the article is to analyze its Common Foreign and Security Policy at the contemporary stage of the evolution of the European Union. The article focuses on the recent initiatives in terms of the reformation and enhancement of this policy area and on the major directions for the implementation of this policy in the context of the existing global and regional challenges. The task of the article is to provide the insight into the evolution of the CFSP from the perspective of both the initiatives for the reformation of this policy area and the EU's reaction on the faced security challenges of the global and regional scale. The major conclusion of the offered analysis is the thesis about the need for further transformation of CFSP, which includes the formation of the synergy with other policies within EU common foreign policy and the spread for CFSP of the common principles and approaches existing in the constitutional order of the EU. Moreover, the article emphasizes the fact that the mentioned process has already been started, despite the existing limitations set by the rules of the Lisbon Treaty.

The Russian aggression in Ukraine, the war in Syria as well as a number of armed conflicts in Northern Africa stressed the growing importance of the security dimension for the EU's future. At the same time, this has led to the enhanced demands of the EU member states for a more energetic EU policy in terms of ensuring international peace and security. Moreover, the enhancement of the CFSP is nowadays considered to be not only as one of the means to promote and protect the EU's values on the international arena but also as an instrument for ensuring strategic autonomy of the EU against the background of the escalating regional and global instability. It should be noted that the enhancement of the CFSP was backed by the European Commission, which should have had other priorities due to the institutional reasons.

Among the major initiatives aimed at the enhancement of the CFSP one should stress the start of Permanent Structured Cooperation (PESCO), and the creation of the European Defence Fund. By forming PESCO the EU member-states agreed 
for the enhanced military cooperation. The goals of this cooperation include the development of the common military capacities, investments in the common defence projects and the readiness to participate in common military operations initiated by decisions of the EU's Council.

The article consists of two parts. The first one concentrates on the analysis of the evolution of the CFSP after the Lisbon treaty and on the initiatives aimed at enhancing this policy articulated and debated in the recent years. The second part focuses on the major direction of the evolution of this policy in the context of the EU's practical reaction on the contemporary challenges.

Key words: CFSP; EU; international security; security challenges; armed conflicts; Neighborhood Policy.

\section{Постановка проблеми}

Від самого свого початку європейська інтеграція мала безпековий вимір. На перших ії етапах основною метою було створення умов для унеможливлення нової війни між Німеччиною та Францією, адже політичні конфлікти між цими країнами були серед головних причин двох світових війн та низки двосторонніх збройних сутичок. Очевидним був і безпековий вимір розширення ЄС після закінчення холодної війни, оскільки цей процес з'єднав європейський континент, поділений свого часу навпіл «залізною завісою». Той фракт, що нові члени ЄС із Центральної та Східної Європи одночасно ставали членами НАТО, лише підкреслює безпекову площину цих процесів. Відповідно, цей аспект залишається присутнім і в контексті відносин ЄС із сусідніми країнами в рамках різноманітних ініціатив, передусім у рамках Європейської політики сусідства та Східного партнерства. Проте нові безпекові виклики для $€ С$, які виникли у зв'язку із його спробами посилити рівень своїх відносин із сусідніми країнами, доволі гостро поставили питання про необхідність модернізації спільної зовнішньої політики та політики безпеки (СЗППБ), яка за правилами Лісабонського договору залишилась окремою політикою в рамках ЄС зі своїми спеціальними правилами формування та реалізації.

Мета

Метою цієї статті $€$ аналіз розвитку СЗППБ на сучасному етап еволюції Європейського Союзу. Буде зроблено спробу проаналізувати не лише останні ініціативи щодо реформування й посилення такої політики, але й основні напрямки реалізації даної політики в контексті глобальних і регіональних викликів.

Завданням статті $€$ висвітлення розвитку СЗППБ на сучасному етапі як точки зору запропонованих ініціатив щодо реформування цієї політики, так із точки зору реакції ЄС на сучасні безпекові виклики глобального та регіонального масштабів.

Аналіз

останніх досліджень і публікацій
Варто зазначити, що зовнішню політику ЄС, право ЄС та окремі його аспекти досліджували українські та зарубіжні вчені, як-от: О. В. Зайчук, М. М. Гнатовський, В. Н. Денисов, А. І. Дмитрієв, А. Я. Капустін, С. Ю. Кашкін, Л. А. Луць, М. Н. Марченко, О. О. Мережко, В. І. Муравйов, К. В. Смирнова, Т. Д. Тимченко, Б. М. Топорнін, Л. М. Ентін та інші.

Основною тезою статті $€$ твердження про необхідність для ЄС трансформації СЗППБ, що включає в себе синергію з іншими політиками в рамках спільної зовнішньої політики ЄС та поширення на СЗППБ загальних принципів і підходів, які існують у консти- туційному порядку ЄС. Підкреслено, що зазначений процес все ж був розпочатий, незважаючи на існуючі обмеження, встановлені правилами Лісабонського договору.

Виклад
основного
матеріалу

Стаття має дві частини. У першій ми акцентуємо увагу на аналізі розвитку СЗППБ у період після початку дії Лісабонського договору та ініціатив, направлених на посилення цієї політики, які отримали розвиток в останні роки. У другій частині розглядаємо основні напрями розвитку цієї політики з точки зору необхідності для ЄС реагувати на сучасні безпекові виклики як глобального, так і регіонального характеру.

Необхідно вказати, що після вступу в дію Лісабонського договору СЗППБ не лише отримала підтвердження своєї важливості на політичному рівні, але й стала предметом серйозних наукових досліджень [14]. Незважаючи на особливі правила щодо ії формування та реалізації, відповідно до статті 2 Договору про функціонування Європейського Союзу СЗППБ була все ж таки формально визнана такою, що належить до компетенції Європейського Союзу. Це призвело до того, що до цієї політики була встановлена юрисдикція Суду ЄС, хоч і в обмеженому обсязі. Іншим наслідком такого визнання став той факт, що СЗППБ повинна відповідати загальним принципам та цілям зовнішньої політики ЄС, як це визначається у статті 23 Договору про Європейський Союз. Такий стан справ указує на необхідність подальшої інтеграції СЗППБ до загальної зовнішньої політики ЄС, попри існуючий особливий інституційний та правовий статус СЗППБ за правилами Лісабонського договору.

Варто підкреслити, що в своїх рішеннях у низці справ [5] Суд ЄС зробив серйозні кроки щодо включання СЗППБ у конституційний устрій ЄС. Зокрема, по відношенню до СЗППБ Суд підкреслив важливість таких конституційних принципів ЄС, як захист фундаментальних прав людини, верховенство права та принцип інституційного балансу - тобто необхідність поважати юрисдикційні межі, як вони встановлені установчими договорами [32]. У справі щодо Угоди про партнерство із Казахстаном [4] Суд окремо вказав на зростаючий зв'язок між СЗППБ та стандартними процедурами в рамках загальних правил правової системи ЄС. У своєму рішенні Суд ЄС підкреслив той факт, що особлива природа СЗППБ не потребує від Суду будь-яких інших підходів, відмінних від тих загальних правил, якими Суд користується при розгляді будь-яких інших справ, що ґрунтуються на праві ЄС. Отже, відповідно до існуючої практики Суду ЄС, яка має прецедентний характер, сьогодні включення СЗППБ до загального конституційного ладу $€ \subset \in$ набагато більшим, ніж це 
передбачено Лісабонським договором. Відповідно, поступово відбувається процес «нормалізації» СЗППБ, тобто застосування до даної політики загальних інституційних, правових та політичних підходів, які $є$ спільними для всіх або більшості політик ЄС. Серед практичних прикладів такої «нормалізації» можна вказати на спільну франко-німецьку декларацію «Відновлюючи обіцяння Європи щодо безпеки та процвітання» від 19 червня 2016 року (Meseberg Declaration). Зокрема, в цій декларації містився заклик до пошуку нових шляхів щодо підвищення швидкості та ефективності процесу прийняття рішень у рамках СЗППБ [8]. Серед таких шляхів зокрема вказувалось на необхідність розглянути можливість прийняття рішень більшістю голосів (або ж кваліфікованою більшістю) щодо СЗППБ. Слід зазначити, що саме така практика прийняття рішень $€$ основною щодо більшості політик $€ С$,,, на відміну від СЗППБ, у рамках якої формальна вимога прийняття рішень - одностайність. Іншим прикладом «нормалізації» СЗППБ є заклики щодо збільшення рівня підзвітності чиновників, які працюють у рамках цієї політики. Відповідно, це означає посилення ролі Європейського парламенту для СЗППБ, що також $є$ загальною тенденцією для ЄС, на відміну від доволі обмеженої ролі Парламенту в рамках СЗППБ.

Переходячи до аналізу сучасних ініціатив щодо СЗППБ, насамперед зауважимо, що російська агресія проти України, війна в Сирії, низка збройних конфліктів у країнах Північної Афррики прискорили розуміння зростаючої важливості безпекових аспектів для подальшого розвитку ЄС. Водночас це призвело до посилення вимог країн-членів щодо більш енергійної політики $€ C$ у сфрері забезпечення міжнародної безпеки. Більш того, зміцнення СЗППБ сьогодні розглядається не лише як засіб для промоції та захисту інтересів і цінностей ЄС на міжнародній арені, але й як інструмент для посилення «стратегічної автономії» $Є С$ на фоні зростаючої глобальної й регіональної нестабільності [3]. Доволі цікавим є і той факт, що посилення СЗППБ було підтримане і Європейською Комісією, яка, здавалося б, має інші інтереси в силу очевидних інституційних причин. Проте в опублікованому документі Комісія закликає ЄС до зміцнення своєї ролі як одного з глобальних політичних гравців шляхом посилення саме СЗППБ, що включає в себе і впровадження більш ефрективного процесу прийняття рішень у рамках такої політики [7].

Серед головних ініціатив, направлених на посилення СЗППБ, слід вказати на формування «Постійного структурованого співробітництва» («Permanent Structured Cooperation» (PESCO)), започаткованого рішенням Ради ЄС від 08.12.2017 р. [6], а також на створення Європейського оборонного фонду [10]. У рамках «Постійного структурованого співробітництва» двадцять п'ять країн-членів ЄС дали згоду на посилене співробітництво в оборонній сфері. Метою такого співробітництва $€$ розвиток дійсно спільних оборонних можливостей ЄС, інвестиції у спільні оборонні проекти та готовність надання власних збройних сил для спільних військових операцій. Керівництво роботи в рамках цієї ініціативи здійснюється Радою ЄС, Високим Представником ЄС зі СЗППБ, яким допомагає Європейська зовнішня служба (European External Action Service).

Щодо Європейського оборонного фонду, то ме- тою його діяльності є підтримка спільного наукового та промислового співробітництва у оборонній сфері між країнами та/або підприємствами, розташованими в $€$. Головним завданням діяльності цього Фонду $\epsilon$ посилення стратегічної автономії ЄС. Варто підкреслити, що створення Фонду було запропоновано Європейською Комісією у формі пропозиції регламенту із посиланням на статті 173 (3) (промисловість), 182 (4), 183 та 188 (2) Договору про функціонування Європейського Союзу. Таким чином додатково підкреслювався взаємний зв'язок між питаннями укріплення оборони, СЗППБ та «спільним ринком», що завжди був основою європейської інтеграції. Відповідно, підкреслюється і необхідність подальшої інтеграції СЗППБ в існуючий правопорядок ЄС з наступною повною нормалізацією цієї політики. Крім очевидних висновків щодо зростаючої ролі СЗППБ для $Є С$ та поступового процесу «комунітаризації» цієї політики, можна вказати й на зовнішні наслідки цього процесу. Вони полягають у тому, що до країн-кандидатів на членство у ЄС починають висуватися умови, які стосуються оборонної сфрери та готовності таких країн щодо інтеграції військо-промислового комплексу в рамках $€ С$ [16].

У другій частині статті ми спробуємо окреслити основні напрямки розвитку цієї політики у контексті необхідності для $€ С$ реагувати на сучасні безпекові виклики. Зокрема, проаналізуємо перспективи еволюції безпекової архітектури ЄС, напрями стратегічної політики та політики щодо викликів у країнах Політики Сусідства.

Розглядаючи постлісабонську еволюцію СЗППБ як окремої політики ЄС, треба вказати на необхідність подальшої трансформації як інституціональної структури, так і процесів щодо прийняття рішень та формування довгострокових стратегій. Зазначимо, що це не перша стаття, присвячена вказаній темі [28]. У рамках існуючої структури процес формування рішень у рамках СЗППБ доволі часто описується як «колективна писанина, а не процес формування стратегічних підходів» [17, с. 11]. Недавні кризи у басейні Середземного моря та в Україні лише підкреслили структурну слабкість європейської зовнішньої політики. Очевидно, що такий стан справ є викликом для $€ С$ і потребує змін, зокрема й змін інституційного порядку. Як показує історія $€ С$, кризи завжди були сигналом для початку дій для зміцнення інституції ЄС та порядку їх взаємодії [12]. Як підкреслюють прибічники неофункціоналізму, кризи завжди розпочинали нові раунди європейської інтеграції [24]. Оскільки ЄС є соціальним конструктом sui generis, варто погодитися з прихильниками історичного інституціоналізму, які вказують, що розуміння $€ C$ можливе лише в процесі історичного аналізу того унікального шляху, яким ЄС іде [39, с. 329].

3 огляду на такий підхід можна говорити про необхідність подальшої конвергенції СЗППБ із іншими напрямками зовнішньої політики ЄС і вироблення єдиної зовнішньої політики. Нещодавні «гібридні» безпекові виклики продемонстрували анахронізм існуючого розколу зовнішньої політики ЄС на СЗППБ та економічні напрямки, як-то: торгівельна політика, політика надання допомоги тощо. Відповідно, замість того, щоб залишатися у сучасному стані ізольованої політики, СЗППБ повинна фрункціонувати як генератор ключових рішень, які б консолідували інші напрями зовнішньої політики 
ЄС [37]. На нашу думку, конвергенція зовнішньої політики ЄС навряд чи має будь-яку розумну альтернативу. Крім того, така конвергенція потребуватиме трансорормації існуючої особливої інституційної системи в рамках СЗППБ. Відповідно, мова також повинна йти і про уніфрікацію як інституційної складової, так і порядку прийняття рішень та їх реалізації.

3 точки зору глобальних стратегії ЄС варто підкреслити два виклики, які є досить незалежними. Перший - це необхідність трансформації безпекової політики $€ C$ з метою протистояння новим викликам, які постають у сучасному світі. Другий - еволюція трансатлантичних відносин. 32003 року, коли була опублікована перша Європейська безпекова стратегія, міжнародна ситуація у сфері безпеки змінилась доволі суттєво. Ці зміни включають у себе трансфрормацію у бік мультиполярного світу та тенденцію щодо занепаду домінування Заходу із одночасним «повстанням Інших» [38]. Здебільшого мова йде про «істернізацію» [33] або ж глобальне зміщення сили у бік Азії [26]. Крім того, все зростаючі геополітичні амбіції Росії говорять про іiї бажання повернутися у коло світових країн-лідерів, що змушує все частіше розглядати Росію як геополітичний безпековий виклик так само, як і агресивний мусульманський фундаменталізм.

Варто зазначити, що відносини між світовими центрами сили часто впливають на становище ЄС Мабуть, найбільш відомий приклад - це постійний величезний вплив американо-російських відносин на безпекове середовище в Європі. Тож життєво важливим для $€ С є$ необхідність стати у сучасному мультиполярному світі одним із глобальних центрів сили. А для цього насамперед треба працювати над зміцненням військового та військово-промислового компонентів європейської інтеграції.

У контексті вищезазначеного зробимо два зауваження. По-перше, зміна самої концепції безпеки, яка спостерігається у сучасному світі. Традиційна концепція безпеки завжди базувалась на захисті територій та національних кордонів від зовнішніх ворогів. Проте у новому тисячолітті ця концепція зазнала критичного переосмислення, результатом якого стало включення в концепцію безпеки цивільних елементів, таких як економічний розвиток, соціальна справедливість, внутрішньополітичні процеси та захист основних прав людини [9]. Такі сучасні безпекові виклики, як російська «гібридна» війна в Україні або ж «Арабська весна», продемонстрували свою складносурядну структуру та значну кількість цивільних елементів поряд із звичними військовими. Крім того, необхідно вказати, що класичні методи агресії та ведення бойових дій поступово замінюються такими методами, як кібератаки, терористичні акти, обмежені операції спеціальних сил, провокація громадянських конфліктів тощо. У сучасному світі концепція безпеки доповнилась такими поняттями, як енергетична безпека, безпека у сфрері захисту навколишнього середовища, соціальна безпека тощо [30, с. 30-33]. Відповідно, у сучасному світі безпекові виклики все частіше асоціюються із комбінацією різноманітних цивільних факторів, які поглиблюються військовими або поліцейськими складовими, такими як бойові дії, можливість терористичних актів, громадянські конфрлікти, піратство тощо.

Друге зауваження стосується «нормалізації» $€ С$ як учасника міжнародних відносин, що включає в себе поступове зміщення акценту із концепції Нормативної Сили [27], яка довгий час залишалась основною, в бік більш традиційних засобів досягнення зовнішньополітичних завдань. Як зазначає більшість фахівців, «структурна зовнішня політика ЄС» [22] покладалась на ідеї І. Канта щодо вічного миру шляхом зовнішньої промоції ліберальних цінностей, що було покладено в основу політичної ідентичності ЄС [36].

Однак акцент на реалізації концепції Нормативної Сили отримав низку критичних зауважень, у тому числі й за концептуальну слабкість [34], та обмежену сореру використання [2]. Більш того, значна кількість досліджень вказувала на те, що концепція Нормативної Сили - це концепція, яка детермінована власними економічними та політичними інтересами ЄC [11], i, відповідно, концепція, яка маскує політику ЄС у власних інтересах ідеалістичними поривами та філософськими концептами [18]. У контексті вказаного, унікальність $€ С$ як учасника міжнародних відносин усе частіше ставиться під сумнів [31].

Цікаво зауважити, що посилання на промоцію універсальних ліберальних цінностей, яке лежало в основі Європейської безпекової стратегії 2003, у Глобальній стратегії ЄС 2016 р. було замінено концепцією «принципового прагматизму». Очевидно, що однією 3 причин такої зміни $є$ переосмислення концепції Нормативної Сили для ЄС. Проте іншою причиною $є$ той факт, що нові глобальні гравці у сучасному мультиполярному світі, формування якого продовжується, свідомо бажають залишатися неліберальними. При цьому при авторитарному стилі правління ці країни отримують довгострокову стабілізацію, або ж навіть укріплення [15]. Китай та Росія $€$ доволі яскравими прикладами зазначеної тези. Більш того, необхідно брати до уваги існуючі обмеження щодо промоції ліберальних цінностей у відносинах із країнами з традиційною ісламською культурою. 3 огляду на вищевказане «нормалізація» $Є С$ як учасника міжнародних відносин означає необхідність повороту до традиційних інструментів зовнішньої політики, що у свою чергу є додатковою причиною для посилення військового компоненту європейської інтеграції.

Говорячи про трансатлантичні відносини, необхідно підкреслити зростаючу необхідність трансформації $€ C$ у більш незалежного та адекватного гравця міжнародних відносин у сфері забезпечення безпеки, незважаючи на важливість НАТО, яка продовжує залишатися наріжним каменем західної безпекової архітектури. Тут необхідно вказати на три самостійні причини для такої трансформації: а) геополітичні, б) політико-економічні та в) безпекові.

Щодо геополітичної перспективи необхідно підкреслити, що Pax Americana - тобто глобальний світовий порядок, який був створений після Другої світової війни, більше не існує. На тлі загальних очікувань того, що світ повинен стати «менш американським» $[1$, с. 1], та послаблення американського впливу у сучасному багатополярному світі [23] трансорормація ЄС у незалежний центр сили в світі вочевидь підкреслює необхідність посилення власної зовнішньої та оборонної політики ЄС. Окрім посилення внутрішньої єдності $€ С$ та його можливості щодо фрормування «єдиного голосу» у міжнародних справах, якості ЄС як учасника міжнародних відносин значною мірою залежать від тих 
інструментів, які останній має у своєму розпорядженні для досягнення своїх зовнішньополітичних завдань. Немає сумніву в тому, що чим більший арсенал таких інструментів, тим більше можливостей він створює. Відповідно, створення власних збройних сил ЄС та політична ідентичність $€ С$ як одного із глобальних центрів сили є обов'язковими умовами для еволюції $€ С$ у повноцінного учасника міжнародних відносин.

3 точки зору політичної економії варто зазначити, що основою військово-політичного співробітництва між США та ЄС завжди були спільні ліберальні цінності. Проте на сучасному етапі міжнародний ліберальний порядок переживає кризу [19]. До того ж, зростаючий популізм як в ЄС, так і в США вказує на зменшення у суспільстві ступеня підтримки неоліберальних цінностей, економічної глобалізації, а також на зростаючий інтерес до власних країн та необхідності концентрації політичних зусиль щодо відстоювання власних національних інтересів. Вибори Президента Д. Трампа в США та його неоднозначні ініціативи щодо реформування НАТО лише підкреслюють трансформації політичних інтересів. Такий розвиток подій $є$ ще однією причиною для лідерів Європи переосмислити роль ЄС у сучасному світі, а також існуючі стратегії ЄС у сфрері міжнародної безпеки.

3 точки зору виключно безпекових причин слід зазначити, що ЄС вимушений відповісти на низку безпекових викликів, які виникли впритул до його кордонів, передусім збройні конфлікти в Україні та в Сирії. Міграційна криза 2015 року яскраво продемонструвала, що $€ С$ може бути безпосередньо та серйозно вражений наслідками розвитку цих конфліктів. Водночас США в силу свого специфічного географічного становища [20] не відчувають жодного впливу цих конфрліктів. Більш того, «Нормандський формат» Мінського мирного процесу є ілюстрацію тези про те, що США «буде поступово виходити із процесів, пов'язаних із розв'язанням конфрліктів, що мають місце в сусідніх із ЄС країнами» [25, с. 9]. На фроні зростаючого тиску безпекових проблем для $€ C[21$, с. 466] та обмежень, «безпекової парасольки НАТО» [13, с. 58], посилення власних безпекових можливостей $€ С$ залишається однією із небагатьох існуючих можливостей.

Аналізуючи безпекові виклики для $€ С$, що мають місце в безпосередній близькості до кордонів $€ C$, варто зауважити, що низка збройних конфліктів, громадянських заворушень та політична нестабільність у більшості країн, які були свого часу включені $€ C$ до Політики Сусідства, перетворилась на окремий чинник європейського політичного життя. Осібне місце у цьому контексті займають бойові дії в Україні та Сирії, які були справедливо визнані реальними загрозами довгостроковим цілям ЄС щодо створення зони миру, стабільності та достатку на межі його кордонів [29, с. 359]. Проте, незважаючи на доволі неоднозначну декларацію про «смерть» Європейської Політики Сусідства [35], ці країни залишаються сусідами ЄС. I безпосередня близькість до ЄС лише підкреслює той негативний вплив, який ці конфлікти створюють для безпеки самого ЄС. Відповідно, вони вимагають особливої уваги як з політичної, так і з безпекової точок зору, а отже, виступають своєрідними каталізаторами подальшої трансформації СЗППБ. Вважаємо, що ті рішення та заходи, які ЄС прийме для подолання про- блем, що виникли в його «задньому дворі», позначать своєрідну траєкторію подальшого розвитку ЄС як одного з головних глобальних гравців.

Необхідно вказати, що конфлікти у країнах-сусідах $€ C$ мають різну природу та різні корені, а отже, відповідно, і різними є рецепти їх подолання. Ці конфлікти можна поділити на дві головні групи: східну (Україна, Грузія, Молдова) та південну (країни Північної Африки та Близького Сходу). Якщо в країнах південної групи необхідно звернути увагу на так званий «фактор ісламського фрундаменталізму», то в країнах східної групи основним деструктивним фактором $є$ російський ревізіонізм, який тримається на імперських амбіціях Росії та ностальгії російського керівництва за часами СРСР. Також варто зазначити, що на відміну від країн південної групи, всі країни східної групи мають не лише очевидні соціально-економічні та політичні подібності, але й серйозні європейські амбіції. Саме кроки цих країн у бік розширення співпраці з ЄС та європеїзації своїх політичних систем і стало причиною такої реакції з боку Росії, яка розглядає розвиток відносин цих країн з ЄС як порушення своїх історичних прав щодо цих територій. Крім того, російська правляча еліта розглядає промоцію $€ С$ ліберальних цінностей в країнах Східного партнерства як екзистенціальну загрозу для путінського авторитарного режиму. Беручи до уваги схильність до використання військових методів для досягнення своїх цілей як прибічників фундаментального ісламу, так і путінської Росії, безпекова складова відносин ЄС із країнами свого сусідства має перетворитися на один із пріоритетних напрямів відносин. У свою чергу, це має виступити одним із факторів для подальшої синергії СЗППБ з іншими напрямками зовнішньої політики ЄС.

Підсумовуючи, можна зробити Висновки такі висновки. По-перше, сучасні глобальні та регіональні безпекові виклики вимагають від $€ С$ посилення військового та військово-промислового співробітництва. По-друге, ця необхідність виступає каталізатором трансорормації СЗППБ та її «нормалізації», що включає в себе і інституційні аспекти, і синергію з іншими політиками в рамках спільної зовнішньої політики $€ С$. По-третє, незважаючи на існуючі обмеження, встановлені правилами Лісабонського договору, вказаний процес транссрормації вже має місце і передбачає реалізацію низки спеціальних ініціатив щодо СЗППБ.

\section{Література:}

1. Alcaro R. The Liberal Order and its Contestations. A Conceptual Framework'. The International Spectator. Special Issue. 2018. №53. №1.

2. Bicchi F. 'Our size fits all': Normative Power Europe and the Mediterranean. Journal of European public policy. 2006. №13(2). P. 286-303.

3. 2016 Global Strategy for the EU's Foreign and Security Policy. URL: http://eeas.europa.eu/archives/ docs/top_stories/pdf/eugs_review_web.pdf.

4. Справа №C-244/17, Commission v. Council, EU: C:2018:662.

5. Справа №C-263/14, Parliament v. Council (Tanzania) EU:C:2016:435; Справа №C-439/13, Elitaliana SpA v. Eulex Kosovo EU:C:2015:753; Справа №C-455/14 P, H v. Council and Commission, EU:C:2016:569. 
6. Council Decision establishing Permanent Structured Cooperation (PESCO) and determining the list of Participating Member States, 8 Dec. 2017.

7. Communication from the Commission to the European Council, the European Parliament and the Council, «A stronger global actor: a more efficient decision-making for EU Common Foreign and Security Policy», COM(2018)647 final.

8. Спільна Франко-Німецька декларація, що відновлює європейські зобов'язання щодо безпеки та процвітання від 19 червня 2016 року. URL: www.diplomatie. gouv.fr/en/country-files/germany/events/article/europefranco-german-declaration-19-06-18.

9. European Security Strategy. A secure Europe in a better world. 12.12.2003. URL: http://www.consilium. europa.eu/uedocs/cmsUpload/78367.pdf

10. Рішення Європейської Комісії від 7 червня 2017 p. Communication from the Commission to the European Parliament, the Council, the European Economic and Social Committee and the Committee of the Regions COM(2017) 295 final.

11. Falkner R. The Political Economy of 'Normative Power' Europe: EU Environmental Leadership in International Biotechnology Regulation. Journal of European Public Policy. 2007. №14(4). P. 507-526.

12. Falkner G. The EU's current crisis and its policy effects: research design and comparative findings. Journal of European Integration. 2016. №38(3). P. 219-235.

13. Fiott D. Improving CSDP Planning and Capability Development: Could there be a 'Frontex Formula'? European Foreign Affairs Review. vol.18. Issue 1. 2013. P. 47-62.

14. Gegout C. European Foreign and Security Policy. University of Toronto Press, 2010. 256 p.

15. Haggard S. and Kaufman R. Democratization During the Third Wave. Annual Review of Political Science. 2016. №1125-144.

16. Hillion C. «Adaptation for autonomy? Candidates for EU membership and the CFSP». 2017. Global Affairs 1.

17. Howorth J., Menon A. Wake up, Europe! Global Affairs. 2015. №1(1). P. 11-20.

18. Hyde-Price A. 'Normative' power Europe: a realist critique. Journal of European Public Policy. 2006. №13(2). P. 217-234.

19. Ikenberry $\mathrm{G}$. The end of liberal International order? International Affairs. 2018. №94:1. P. 7-23.

20. Ikenberry G. The illusion of geopolitics: The enduring power of the liberal order. Foreign Affairs. 2014. №93. P. 80-90.

21. Klein N. \& Wessels W. CFSP Progress or Decline after Lisbon? European Foreign Affairs Review. Vol. 18. Issue 4. 2013. P. 449-469.

22. Keukeleire S., Delreux T. The Foreign Policy of the European Union. London: Red Globe Press, 2014. 408 p.

23. Layne C. This time it's real: The end of unipolarity and the Pax Americana. International Studies Quarterly. 2012. №56(1). P. 203-213.

24. Lefkofridi Z., Schmitter P. Transcending or descending? European integration in times of crisis. European Political Science Review. 2015. №7(01). P. 3-22.

25. Lehne S. The Big Three in EU Foreign Policy. The Carnegie Papers. 2012. URL: www.carnegieendowment. org.
26. Mahbubani K. The new Asian hemisphere: The irresistible shift of global power to the East. New York : Public Affairs, 2008. 314 p.

27. Manners I. Normative Power Europe: A Contradiction in Terms? JCMS. 2002. №40(2). P. 235-258.

28. Moskalenko O. 'Parlamentarization' of the CFSP: wishful thinking or a rational choice? Croatian Yearbook of European Law and Policy. 2016. Vol. 12. P. 251-273.

29. Müller P. EU foreign policy: no major breakthrough despite multiple crises. Journal of European Integration. 2016. №38:3. P. 359-374.

30. Naumescu V. «Spațiul securității europene» în British Council. Studii de securitate. Cavallioti, 2005.

31. Niemann A. and Bretherton C. EU external policy at the crossroads: the challenge of actorness and effectiveness. International Relations. 2013. №27(3). P. 261-275.

32. Poli S. The Common Foreign Security Policy after Rosneft: Still imperfect but gradually subject to the rule of law. Common Market Law Review. (2017)54. Issue 6. P. 1799-1834.

33. Rachman G. Easternisation: War and Peace in the Asian Century. London: Bodley Head, 2016. 288 p.

34. Sjursen H. The EU as a 'Normative' Power: How Can This Be? Journal of European Public Policy. 2006. №13(2). P. 235-251.

35. Tocci N. The Neighborhood Policy is Dead. What's Next for European Foreign Policy Along its Arc of Instability? Instituto Affari Internazionali. IAI Working Papers. №14. 2014.

36. Values and Principles in European Foreign Policy / eds. S. Lucarelli and I. Manners. London and New York: Routledge, 2006.

37. Wouters J. and K. Raube Europe's Common Security and Defence Policy: The Case for InterParliamentary Scrutiny. Leuven Centre for Global Governance Studies. Working Paper. 2012. №90.

38. Zakaria F. The Post-American World and the Rise of the Rest. New York: Norton, 2008. 304 p.

39. Zumbansen P. Review Essay - Europe's 'Darker Legacies'? Notes on 'Mirror Reflections', the 'Constitution as Fetish' and Other Such Linkages between the Past and the Future. Osgoode Hall Law Journal. 2005. №43. P. 321-334. 